\title{
Evaluation and Analysis of CBA Referees' on-the-spot Cutting
}

\author{
Shi $\mathrm{Li}^{1, \mathrm{a}}$, Kai Yan ${ }^{2, \mathrm{~b}}$, Jinsheng $\mathrm{Li}^{3, \mathrm{c}}$ \\ ${ }^{1}$ China, PhD in Tianjin University, Professor of Tianjin University of Sport, and Master Instructor; \\ Address Tianjin Weijin South Road 51 \\ ${ }^{2}$ China, Current Master Students in Tianjin University of Sport. Address:Tianjin Weijin South \\ Road 51 \\ ${ }^{3}$ China, Director of the Basketball Management Center of the State Sports General \\ Administration, vice chairman of the China Basketball Association. Address: Beijing \\ Guangqumennei Street 80.

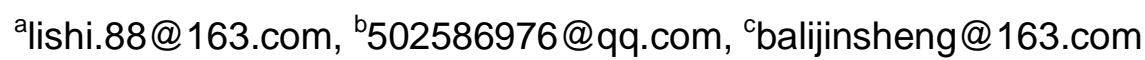

Keywords: Referees, CBA, Error rate, Missed rate.

\begin{abstract}
Through the spot investigation and research, and watching the CBA basketball referees' on-the-spot cutting, this topic using literature method, observation method, system analysis method, mathematical statistics method and logical analysis method, combined with the self-designed "basketball referees' on-the-spot cutting assessment system(CAA)" to develop a more accurate evaluation of the indicators for the level of referees' on-the-spot cutting. Through the assessment results, to establish the referees database, then provide a more reasonable basis for the referees‘ promotion and make it more convincing.
\end{abstract}

\section{Introduction}

In the 17 years of development process of China's basketball professional league, the level of the league has made great progress, and professional basketball market reached to a certain level. As a part of the basketball game, the basketball referee is an important part of the game, because the referee's penalty may directly affect the outcome of the game or even the results. The current referee controversial issues continue to emerge, one of the most significant problem is the referee's penalty. In recent years, with the introduction of high-level foreign aid, CBA competition is on the increasingly fierce competition, but the level of the referee has been stagnant. All kinds of misjudgment, commutation, missed one after another, even the shout " Black whistle " from the fans is intensified.

The accuracy of the basketball referees' on-the-spot cutting directly affects the level of competition of the basketball game. Most of our country's basketball referees are part-time, the level of professional and technical is limited by a certain. There have been few studies on the systematic, objective and impartial evaluation of the referee's spot performance for a long time. Through the investigation of the referees' on-the-spot cutting, this article develops a more accurate evaluation of the level of referees' on-the-spot cutting. The independently designed "basketball referees' on-the-spot cutting assessment system (CAA)" using the traditional C / S (client / server) for the architecture design. The front desk using the Microsoft .NET Framework 4.0 for the interface design. And it using Microsoft Office Access database for the storage of front and back data. Central database will be stored in front and back of the Access data into MySQL data for storage and query. The central database will get the back and forth data together, to provide a unified storage format, and improve the data security level. To be uesd throughout the country's 17 games, each referee monitor has a Acer ICONIA TAB (ICONA_Tab_W500 -C62G03iss EAB00) for the spot operation. The supervisor is responsible for the data collection of the referee on duty and delivery the data after confirming the correctness by the post-match supervisor. Through the qualitative and quantitative aspects of the referee to assess the performance of the referee 
on-the-spot cutting to provide a certain theoretical basis for the assessment of the level of the accuracy.

\section{Study Object}

The evaluation of 2012-2013 season CBA basketball referee on-the-spot cutting .

\section{Research Methods}

\subsection{Document method}

According to the purpose and content of the study, access to a large number of literature related to basketball referees.

\subsection{Observation method}

Live view, statistics referees' on-the-spot cutting

\subsection{Mathematical Statistics}

Analyze the data statistically.

\subsection{Logical Analysis}

Using the special research theory and methods for the multi-angle analysis of statistical results, on the basis, using logical reasoning method for comprehensive analysis.

\section{Results and Analysis}

4.1 Correlation analysis of CBA referees' on-the-spot referee score, the average score, the standard deviation; and the referee error rate.

4.1.1 Correlation Analysis between Objective Factors and CBA Referees' on-the-spot cutting.

\begin{tabular}{|c|c|r|r|r|r|r|r|}
\hline & $\begin{array}{c}\text { The } \\
\text { person } \\
\text { in } \\
\text { charge }\end{array}$ & $\begin{array}{r}\text { Competition } \\
\text { supervision }\end{array}$ & $\begin{array}{r}\text { The } \\
\text { home } \\
\text { team } \\
\text { coach }\end{array}$ & $\begin{array}{r}\text { The } \\
\text { visiting } \\
\text { team } \\
\text { coach }\end{array}$ & $\begin{array}{r}\text { Technical } \\
\text { representative }\end{array}$ & $\begin{array}{r}\text { Live } \\
\text { media }\end{array}$ & $\begin{array}{r}\text { Total } \\
\text { score }\end{array}$ \\
\hline Average & 4.5 & 16.6 & 9.0 & 7.9 & 43.0 & 4.0 & 4.5 \\
\hline $\begin{array}{c}\text { Standard } \\
\text { deviation }\end{array}$ & 0.35 & 1.63 & 0.74 & 1.44 & 2.95 & 0.53 & 0.35 \\
\hline
\end{tabular}

Person in charge: 5 points; competition supervision: 20 points; home team coach: 10 points; visiting coach: 10 points; technical representative: 50 points; live media: 5 points.

From the results in the table we can get the correlation analysis between the average score、 the standard deviation of the points and the rate of the referees' error as the following table shows. The main method is variance analysis method for the degree of correlation analysis.

4.1.2 The error rate, the average and the standard deviation of CBA referees' on-the -spot cutting.

\begin{tabular}{|c|r|r|r|r|r|}
\hline & $\begin{array}{r}\text { Correct } \\
\text { rate }\end{array}$ & $\begin{array}{r}\text { Serious missed } \\
\text { rate }\end{array}$ & $\begin{array}{r}\text { Serious error } \\
\text { rate }\end{array}$ & $\begin{array}{r}\text { Missed } \\
\text { rate }\end{array}$ & $\begin{array}{c}\text { Error } \\
\text { rate }\end{array}$ \\
\hline Average & $84.15 \%$ & $0.15 \%$ & $0.06 \%$ & $11.15 \%$ & $4.49 \%$ \\
\hline $\begin{array}{c}\text { Standard } \\
\text { deviation }\end{array}$ & 0.07474 & 0.00841 & 0.00322 & 0.06024 & 0.04196 \\
\hline
\end{tabular}

4.1.3 Related consistency of scores of person in charge of the contest, competition supervision, home team and visiting team coach, technical representative and media. 


\begin{tabular}{|c|c|c|c|c|c|c|c|c|}
\hline & & $\begin{array}{l}\text { Person } \\
\text { of the } \\
\text { charge }\end{array}$ & $\begin{array}{l}\text { Competition } \\
\text { supervision }\end{array}$ & $\begin{array}{l}\text { Home } \\
\text { team } \\
\text { coach }\end{array}$ & $\begin{array}{l}\text { Visiting } \\
\text { team } \\
\text { coach }\end{array}$ & $\begin{array}{c}\text { Technical } \\
\text { representative }\end{array}$ & $\begin{array}{r}\text { Live } \\
\text { media }\end{array}$ & $\begin{array}{l}\text { Error } \\
\text { rate }\end{array}$ \\
\hline \multirow{3}{*}{$\begin{array}{l}\text { Person } \\
\text { of the } \\
\text { charge }\end{array}$} & $\begin{array}{l}\text { Pearson } \\
\text { Correlation }\end{array}$ & 1 & .030 & $.266^{*}$ & -.053 & -.017 & .033 & -.042 \\
\hline & $\begin{array}{l}\text { Sig. } \\
\text { (2-tailed) }\end{array}$ & & .783 & .012 & .623 & .875 & .756 & .698 \\
\hline & $\mathrm{N}$ & 89 & 89 & 89 & 89 & 89 & 89 & 89 \\
\hline \multirow{3}{*}{$\begin{array}{l}\text { Compet } \\
\text { ition } \\
\text { supervi } \\
\text { sion }\end{array}$} & $\begin{array}{l}\text { Pearson } \\
\text { Correlation }\end{array}$ & .030 & 1 & -.034 & $.230^{*}$ & $.487^{* *}$ & -.058 & .028 \\
\hline & $\begin{array}{l}\text { Sig. } \\
\text { (2-tailed) }\end{array}$ & .783 & & .752 & .030 & .000 & .587 & .793 \\
\hline & $\mathrm{N}$ & 89 & 89 & 89 & 89 & 89 & 89 & 89 \\
\hline \multirow{3}{*}{$\begin{array}{l}\text { Home } \\
\text { team } \\
\text { coach }\end{array}$} & $\begin{array}{l}\text { Pearson } \\
\text { Correlation }\end{array}$ & $.266^{*}$ & -.034 & 1 & .042 & .168 & .196 & -.133 \\
\hline & $\begin{array}{l}\text { Sig. } \\
\text { (2-tailed) }\end{array}$ & .012 & .752 & & .698 & .115 & .066 & .213 \\
\hline & $\mathrm{N}$ & 89 & 89 & 89 & 89 & 89 & 89 & 89 \\
\hline \multirow{3}{*}{$\begin{array}{l}\text { Visiting } \\
\text { team } \\
\text { coach }\end{array}$} & $\begin{array}{l}\text { Pearson } \\
\text { Correlation }\end{array}$ & -.053 & $.230^{*}$ & .042 & 1 & $.442^{* *}$ & .118 & -.089 \\
\hline & $\begin{array}{l}\text { Sig. } \\
\text { (2-tailed) }\end{array}$ & .623 & .030 & .698 & & .000 & .271 & .406 \\
\hline & $\mathrm{N}$ & 89 & 89 & 89 & 89 & 89 & 89 & 89 \\
\hline \multirow{3}{*}{$\begin{array}{l}\text { Technic } \\
\text { al } \\
\text { represe } \\
\text { ntative }\end{array}$} & $\begin{array}{l}\text { Pearson } \\
\text { Correlation }\end{array}$ & -.017 & $.487^{* *}$ & .168 & $.442^{* *}$ & 1 & .185 & -.062 \\
\hline & $\begin{array}{l}\text { Sig. } \\
\text { (2-tailed) }\end{array}$ & .875 & .000 & .115 & .000 & & .083 & .563 \\
\hline & $\mathrm{N}$ & 89 & 89 & 89 & 89 & 89 & 89 & 89 \\
\hline \multirow[t]{3}{*}{$\begin{array}{l}\text { Live } \\
\text { media }\end{array}$} & $\begin{array}{l}\text { Pearson } \\
\text { Correlation }\end{array}$ & .033 & -.058 & .196 & .118 & .185 & 1 & -.002 \\
\hline & $\begin{array}{l}\text { Sig. } \\
\text { (2-tailed) }\end{array}$ & .756 & .587 & .066 & .271 & .083 & & .987 \\
\hline & $\mathrm{N}$ & 89 & 89 & 89 & 89 & 89 & 89 & 89 \\
\hline \multirow[t]{3}{*}{$\begin{array}{l}\text { Error } \\
\text { rate }\end{array}$} & $\begin{array}{l}\text { Pearson } \\
\text { Correlation }\end{array}$ & -.042 & .028 & -.133 & -.089 & -.062 & -.002 & 1 \\
\hline & $\begin{array}{l}\text { Sig. } \\
\text { (2-tailed) }\end{array}$ & .698 & .793 & .213 & .406 & .563 & .987 & \\
\hline & $\mathrm{N}$ & 89 & 89 & 89 & 89 & 89 & 89 & 89 \\
\hline \multicolumn{9}{|c|}{ *. Correlation is significant at the 0.05 level (2-tailed). } \\
\hline **. Corre & on is signific & the 0 & 1 level (2-ta & & & & & \\
\hline
\end{tabular}

As a result, it can be seen that there is no significant positive correlation between the scores and the error rate, except that the results of the competition supervision are positively related to the positive error rate. Therefore, speculating the scores of other scorers are not only dependent on the error rate. It can be seen that the competition supervisor's scoring criteria are mainly based on the judgment error rate of the referee, and the competition leader, home team and visiting team coach, technical representative and media scoring standards are different. Referee's error rate is not the main scoring basis. A personal subjective factors may be included, and technical representatives may be more consider the referee's comprehensive management capabilities. 


\subsection{Analysis of CBA referees' on-the-spot cutting in the regular season.}

4.2.1 Average, standard deviation and the correct rate in the regular season, 1/4, 1/2 and the finals.

\begin{tabular}{|c|c|c|c|c|c|}
\hline Term & $\begin{array}{c}\text { Correct } \\
\text { rate }\end{array}$ & $\begin{array}{l}\text { Serious } \\
\text { missed rate }\end{array}$ & $\begin{array}{c}\text { Serious } \\
\text { error rate }\end{array}$ & Missed rate & Error rete \\
\hline $\begin{array}{c}\text { Regular } \\
\text { season }\end{array}$ & $88.37 \%$ & $0.06 \%$ & $0.04 \%$ & $7.72 \%$ & $3.81 \%$ \\
\hline $1 / 4$ & $87.96 \%$ & $0.00 \%$ & $0.04 \%$ & $7.85 \%$ & $4.19 \%$ \\
\hline $1 / 2$ & $89.78 \%$ & $0.00 \%$ & $0.00 \%$ & $4.47 \%$ & $5.75 \%$ \\
\hline Final & $97.42 \%$ & $0.00 \%$ & $0.00 \%$ & $1.72 \%$ & $0.86 \%$ \\
\hline Average & $\mathbf{9 0 . 8 8 \%}$ & $\mathbf{0 . 0 1 \%}$ & $\mathbf{0 . 0 1 \%}$ & $\mathbf{5 . 4 4 \%}$ & $\mathbf{3 . 6 5 \%}$ \\
\hline $\begin{array}{c}\text { Standard } \\
\text { deviation }\end{array}$ & $\mathbf{0 . 0 4 4 3 0 9}$ & $\mathbf{0 . 0 0 0 2 9 7}$ & $\mathbf{0 . 0 0 0 1 9 8}$ & $\mathbf{0 . 0 2 9 3 4 0 9 6}$ & $\mathbf{0 . 0 2 0 4 3 1}$ \\
\hline
\end{tabular}

From the table it can be seen that the highest correct rate is in the finals, followed by the one-in-two finals, the worst is the regular seasons and quarter finals. It shows the referee arrangements, the level of referees and the degree of emphasis on the game at all stages. Missed and the error rate is mainly concentrated in the regular seasons, and the difference between the missed rate is very significant.

4.2.2 Analysis of average, standard deviation and the correct rate of CBA referees' on-the-spot cutting in each section of the regular season.

\begin{tabular}{|c|c|c|c|c|c|c|}
\hline \multirow{2}{*}{ Term } & Section & Correct rate & $\begin{array}{l}\text { Serious } \\
\text { missed } \\
\text { rate }\end{array}$ & $\begin{array}{l}\text { Serious } \\
\text { error rate }\end{array}$ & Missed rate & Error rate \\
\hline \multirow{2}{*}{$\begin{array}{c}\text { Regular } \\
\text { season }\end{array}$} & 1 & $87.36 \%$ & $0.03 \%$ & 0 & $8.75 \%$ & $3.86 \%$ \\
\cline { 2 - 7 } & 2 & $87.13 \%$ & $0.03 \%$ & $0.03 \%$ & $8.30 \%$ & $4.51 \%$ \\
\cline { 2 - 7 } & 3 & $88.43 \%$ & $0.11 \%$ & $0.08 \%$ & $7.68 \%$ & $3.71 \%$ \\
\cline { 2 - 7 } & 5 & $90.26 \%$ & $0.08 \%$ & $0.05 \%$ & $6.43 \%$ & $3.18 \%$ \\
\cline { 2 - 7 } & 6 & $100.00 \%$ & - & 0 & $-2.02 \%$ & $5.05 \%$ \\
\hline Average & & $\mathbf{9 1 . 0 2 \%}$ & $\mathbf{0 . 0 4 \%}$ & $\mathbf{0 . 0 3 \%}$ & $\mathbf{5 . 5 3 \%}$ & $3.38 \%$ \\
\hline $\begin{array}{l}\text { Standard } \\
\text { deviation }\end{array}$ & & $\mathbf{4 . 9 0 \%}$ & $\mathbf{0 . 0 4 \%}$ & $\mathbf{0 . 0 3 \%}$ & $\mathbf{3 . 6 4 \%}$ & $\mathbf{1 . 7 8 \%}$ \\
\hline
\end{tabular}

It can be seen from the above table that in each section of the regular season, the missed rate and the error rate is very high. The biggest difference of missed rate is concentrated in the first and second section. The biggest difference of the error rate is the second section and the overtime period of the first section. It shows that CBA referees should work hard on the basic skills. 


\subsection{Comparison analysis of CBA referees' on-the-spot cutting in the regular season.}

\subsubsection{Contrast of R (referee), U1 (first deputy referee), U2 (second deputy referee)}

\begin{tabular}{|c|c|c|c|c|c|c|c|c|}
\hline Term & Referee & $\begin{array}{c}\text { The total } \\
\text { number } \\
\text { of } \\
\text { penalties }\end{array}$ & $\begin{array}{c}\text { Correct } \\
\text { rate }\end{array}$ & $\begin{array}{l}\text { Error } \\
\text { rate }\end{array}$ & $\begin{array}{l}\text { Serious } \\
\text { missed } \\
\text { rate }\end{array}$ & $\begin{array}{l}\text { Serious } \\
\text { error rate }\end{array}$ & $\begin{array}{l}\text { Missed } \\
\text { rate }\end{array}$ & Error rate \\
\hline $\begin{array}{c}\text { Regular } \\
\text { season }\end{array}$ & $\mathrm{R}$ & 5900 & 0.9203 & 0.0797 & 0.000339 & 0.000169492 & 0.04678 & 0.032373 \\
\hline & $\mathrm{U} 1$ & 5070 & 0.8870 & 0.1130 & 0.0003945 & 0 & 0.074753 & 0.03787 \\
\hline & $\mathrm{U} 2$ & 4170 & 0.8278 & 0.1722 & 0.001199 & 0.001199041 & 0.123261 & 0.046523 \\
\hline Average & & & 0.8784 & 0.1216 & 0.0006442 & 0.000456177 & 0.081598 & 0.038922 \\
\hline $\begin{array}{c}\text { Standard } \\
\text { deviatio } \\
\mathrm{n}\end{array}$ & & 0.0469 & 0.04685 & 0.0004813 & 0.000648896 & 0.038698 & 0.007133 \\
\hline
\end{tabular}

R's total number of whistles is the largest, followed by U1, and finally U2; the correct rate is the same order, and there are significant differences. And it is consistent with the fact that the referee administration only consider their actual ability in the referee arrangement and the abolition of the referee level.

4.3.2 Comparative analysis of the correct number of the whistles of the home teams and visiting teams.

\begin{tabular}{|c|c|c|c|c|c|}
\hline \multicolumn{2}{|c|}{ Paired sample statistics } \\
\hline \multicolumn{2}{|c|}{} & Average & $\mathrm{N}$ & $\begin{array}{c}\text { Standard } \\
\text { deviation }\end{array}$ & $\begin{array}{c}\text { Standard Error of } \\
\text { average }\end{array}$ \\
\hline pair 1 & $\begin{array}{l}\text { Home } \\
\text { teams }\end{array}$ & 407.5882 & 17 & 33.23789 & 8.06137 \\
\hline
\end{tabular}

Through the paired t test, it is considered that there are significant differences in the number of correct times between the home team and the visiting team.

4.3.3Comparative analysis of the correct rate of the whistles of the home teams and visiting teams.

\begin{tabular}{|c|c|c|c|c|c|c|c|c|c|}
\hline \multicolumn{10}{|c|}{ Pairwise sample test } \\
\hline & & \multicolumn{5}{|c|}{ Pair of differentials } & \multirow[t]{3}{*}{$\mathrm{t}$} & \multirow[t]{3}{*}{ df } & \multirow{3}{*}{$\begin{array}{l}\text { Sig. } \\
\text { (two } \\
\text { side) }\end{array}$} \\
\hline & & \multirow[t]{2}{*}{ Average } & \multirow[t]{2}{*}{$\begin{array}{l}\text { Standard } \\
\text { deviation }\end{array}$} & \multirow{2}{*}{$\begin{array}{l}\text { Standard } \\
\text { Error of } \\
\text { average }\end{array}$} & \multicolumn{2}{|c|}{$\begin{array}{l}\text { Differential } 95 \% \\
\text { confidence interval }\end{array}$} & & & \\
\hline & & & & & $\begin{array}{c}\text { Bottom } \\
\text { limit }\end{array}$ & $\begin{array}{l}\text { Upper } \\
\text { limit }\end{array}$ & & & \\
\hline pair 1 & $\begin{array}{l}\text { Home } \\
\text { teams - } \\
\text { Visiting } \\
\text { teams }\end{array}$ & -.00388 & .04972 & .01206 & -.02945 & .02168 & -.322 & 16 & .752 \\
\hline
\end{tabular}

Through the paired t test, it shows that the correct rates are different between home teams and visiting teams.

The correct rate of 47 people are more than $85 \%$, accounting for $55 \%$ of the total; the correct rate of 39 people are less than $85 \%$, accounting for $45 \%$ of the total number of people. It shows that the referees should strive to improve the accuracy of the penalty. 


\begin{tabular}{|c|c|c|c|c|c|c|c|c|c|}
\hline \multicolumn{10}{|c|}{ Pairwise sample test } \\
\hline & & \multicolumn{5}{|c|}{ Pair of differentials } & \multirow[t]{3}{*}{$\mathrm{t}$} & \multirow[t]{3}{*}{ df } & \multirow{3}{*}{$\begin{array}{l}\text { Sig.(two } \\
\text { sides) }\end{array}$} \\
\hline & & \multirow[t]{2}{*}{ Average } & \multirow[t]{2}{*}{$\begin{array}{l}\text { Standard } \\
\text { deviation }\end{array}$} & \multirow{2}{*}{$\begin{array}{l}\text { Standard } \\
\text { Error of } \\
\text { average }\end{array}$} & \multicolumn{2}{|c|}{$\begin{array}{l}\text { Differential } 95 \% \\
\text { confidence interval }\end{array}$} & & & \\
\hline & & & & & $\begin{array}{c}\text { Bottom } \\
\text { limit }\end{array}$ & $\begin{array}{l}\text { Upper } \\
\text { limit }\end{array}$ & & & \\
\hline pair 1 & $\begin{array}{l}\text { Home } \\
\text { teams } \\
\text {-Visiting } \\
\text { teams }\end{array}$ & $\begin{array}{l}-33.4705 \\
9\end{array}$ & 50.92411 & 12.35091 & $\begin{array}{c}-59.653 \\
35\end{array}$ & $\begin{array}{c}-7.287 \\
83\end{array}$ & -2.710 & 16 & .015 \\
\hline
\end{tabular}

\subsection{Comparative analysis of fouls and violations of home teams and visiting teams.}

4.4.1 Comparative analysis of the differences between the fouls of home teams and visiting homes.

\begin{tabular}{|c|c|c|c|c|c|c|c|c|c|}
\hline \multicolumn{10}{|c|}{ Pairwise sample test } \\
\hline & & \multicolumn{5}{|c|}{ Pair of differentials } & \multirow[t]{3}{*}{$\mathrm{t}$} & \multirow[t]{3}{*}{$\mathrm{df}$} & \multirow{3}{*}{$\begin{array}{l}\text { Sig.(two } \\
\text { sides) }\end{array}$} \\
\hline & & \multirow[t]{2}{*}{ Average } & \multirow[t]{2}{*}{$\begin{array}{l}\text { Standard } \\
\text { deviation }\end{array}$} & \multirow{2}{*}{$\begin{array}{l}\text { Standar } \\
\text { d Error } \\
\text { of } \\
\text { average }\end{array}$} & \multicolumn{2}{|c|}{$\begin{array}{l}\text { Differential } 95 \% \\
\text { confidence interval }\end{array}$} & & & \\
\hline & & & & & $\begin{array}{c}\text { Bottom } \\
\text { limit }\end{array}$ & $\begin{array}{l}\text { Upper } \\
\text { limit }\end{array}$ & & & \\
\hline pair 1 & $\begin{array}{l}\text { Visiting } \\
\text { teams- } \\
\text { Home } \\
\text { teams }\end{array}$ & $\begin{array}{c}23.3529 \\
4\end{array}$ & 34.86392 & $\begin{array}{c}8.4557 \\
4\end{array}$ & 5.42757 & $\begin{array}{c}41.278 \\
31\end{array}$ & $\begin{array}{l}2.7 \\
62\end{array}$ & 16 & .014 \\
\hline
\end{tabular}

Through the paired analysis, it is considered that there is a significant difference between the home teams and visiting teams in fouls. For some clubs, the number of fouls away from home is more than the number of fouls at home, and for some clubs the number of fouls at home is more than away from home.

\subsubsection{Comparative analysis of Offensive between home teams and visiting teams.}

Through the paired test, that the number of violations at home and away from home are

\begin{tabular}{|c|c|c|c|c|c|c|c|c|c|}
\hline & & Pair of di & entials & & & & $\mathrm{t}$ & $\overline{\mathrm{df}}$ & Sig. \\
\hline & & Average & $\begin{array}{l}\text { Standard } \\
\text { deviation }\end{array}$ & $\begin{array}{l}\text { Standard } \\
\text { Error of }\end{array}$ & $\begin{array}{l}\text { Differen } \\
\text { confiden }\end{array}$ & $\begin{array}{l}95 \% \\
\text { interval }\end{array}$ & & & $\begin{array}{l}\text { (two } \\
\text { side) }\end{array}$ \\
\hline & & & & average & $\begin{array}{c}\text { Bottom } \\
\text { limit }\end{array}$ & $\begin{array}{c}\text { Upper } \\
\text { limit }\end{array}$ & & & \\
\hline pair 1 & $\begin{array}{l}\text { Visiting } \\
\text { teams- } \\
\text { Home } \\
\text { teams }\end{array}$ & 11.88235 & $\begin{array}{l}1.49 \\
832\end{array}$ & 10.06482 & $\begin{array}{c}-9.4541 \\
1\end{array}$ & $\begin{array}{c}33.2188 \\
2\end{array}$ & $\begin{array}{l}1.1 \\
81\end{array}$ & 16 & .255 \\
\hline
\end{tabular}

significantly different, and some clubs' violations are significantly more than at home, and some clubs' violations are significantly less than at home. 
4.4.3 Comparative analysis of victories, the average and the standard deviation between home teams and visiting teams.

\begin{tabular}{|c|c|c|c|c|c|c|c|c|c|}
\hline \multicolumn{10}{|c|}{ Pairwise sample test } \\
\hline & & \multicolumn{5}{|c|}{ Pair of differentials } & \multirow[t]{3}{*}{$\mathrm{t}$} & \multirow[t]{3}{*}{$\mathrm{df}$} & \multirow{3}{*}{$\begin{array}{l}\text { Sig. } \\
\text { (two } \\
\text { sides) }\end{array}$} \\
\hline & & \multirow[t]{2}{*}{$\begin{array}{c}\text { Aver } \\
\text { age }\end{array}$} & \multirow[t]{2}{*}{ Standarddeviation } & \multirow[t]{2}{*}{$\begin{array}{l}\text { Standard } \\
\text { Error of } \\
\text { average }\end{array}$} & \multicolumn{2}{|c|}{$\begin{array}{c}\text { Differential 95\% } \\
\text { confidence } \\
\text { interval }\end{array}$} & & & \\
\hline & & & & & $\begin{array}{l}\text { Bottom } \\
\text { limit }\end{array}$ & $\begin{array}{c}\text { Upper } \\
\text { limit }\end{array}$ & & & \\
\hline pair 1 & $\begin{array}{l}\text { Victories } \\
\text { of } \\
\text { visiting } \\
\text { teams \& } \\
\text { Victories } \\
\text { of home } \\
\text { teams }\end{array}$ & $\begin{array}{c}-4.94 \\
118\end{array}$ & 2.92555 & .70955 & $\begin{array}{c}-6.4453 \\
5\end{array}$ & $\begin{array}{c}-3.43 \\
700\end{array}$ & $\begin{array}{l}-6.9 \\
64\end{array}$ & 16 & .000 \\
\hline
\end{tabular}

Through the paired test, that the number of victories has significant difference between home teams and visiting teams. The number of victories of home teams is more than the visiting teams. 4.4.4 Comparative analysis of failure, the average and the standard deviation between home teams and visiting teams.

\begin{tabular}{|c|c|c|c|c|c|c|c|c|c|}
\hline \multicolumn{10}{|c|}{ Pairwise sample test } \\
\hline & & \multicolumn{5}{|c|}{ Pair of differentials } & \multirow[t]{3}{*}{$\mathrm{t}$} & \multirow[t]{3}{*}{$\mathrm{df}$} & \multirow{3}{*}{$\begin{array}{l}\begin{array}{l}\text { Sig. } \\
\text { (two } \\
\text { sides) }\end{array}\end{array}$} \\
\hline & & \multirow[t]{2}{*}{ Average } & \multirow[t]{2}{*}{$\begin{array}{l}\text { Standard } \\
\text { deviation }\end{array}$} & \multirow{2}{*}{$\begin{array}{l}\text { Standard } \\
\text { Error of } \\
\text { average }\end{array}$} & \multicolumn{2}{|c|}{$\begin{array}{c}\text { Differential 95\% } \\
\text { confidence interval }\end{array}$} & & & \\
\hline & & & & & $\begin{array}{l}\text { Bottom } \\
\text { limit }\end{array}$ & $\begin{array}{l}\text { Upper } \\
\text { limit }\end{array}$ & & & \\
\hline Pair1 & $\begin{array}{l}\text { Failures } \\
\text { of } \\
\text { visiting } \\
\text { teams - } \\
\text { Failures } \\
\text { of } \\
\text { home } \\
\text { teams }\end{array}$ & $\begin{array}{r}-4.941 \\
18\end{array}$ & 2.83881 & .68851 & -6.40076 & $\begin{array}{r}-3.4816 \\
0\end{array}$ & $\begin{array}{r}-7.17 \\
7\end{array}$ & 16 & .000 \\
\hline
\end{tabular}

Through the paired test, it is considered that there is a significant difference between the number of failures at home and away from home, and the number of home failures is less than that of away from home. 
In addition,the comparison of average and standard deviation are as follows:

\begin{tabular}{|c|c|c|c|c|c|c|c|c|c|c|c|c|c|c|}
\hline Teams & $\begin{array}{c}\text { Number of } \\
\text { Games }\end{array}$ & $\begin{array}{c}\text { Victories } \\
\text { Visiting } \\
\text { Teams }\end{array}$ & $\%$ & $\begin{array}{c}\text { Victories } \\
\text { of Home } \\
\text { Teams }\end{array}$ & $\%$ & $\begin{array}{c}\text { Total } \\
\text { Victories }\end{array}$ & $\begin{array}{c}\text { Failures } \\
\text { of } \\
\text { Visiting } \\
\text { Teams }\end{array}$ & $\begin{array}{c}\text { Failures } \\
\text { of } \\
\text { Home } \\
\text { Teams }\end{array}$ & $\%$ & $\begin{array}{c}\text { Total } \\
\text { Failures }\end{array}$ & $\begin{array}{c}\text { Total } \\
\text { Scores }\end{array}$ \\
\hline Bayi & 32 & 6 & $18.8 \%$ & 10 & $31.3 \%$ & 16 & $50.0 \%$ & 6 & $18.8 \%$ & 10 & $31.3 \%$ & 16 & $50.0 \%$ & 3013 \\
\hline Beijing & 32 & 8 & $25.0 \%$ & 13 & $40.6 \%$ & 21 & $65.6 \%$ & 3 & $9.4 \%$ & 8 & $25.0 \%$ & 11 & $34.4 \%$ & 3334 \\
\hline Dongguan & 33 & 7 & $21.2 \%$ & 11 & $33.3 \%$ & 18 & $54.5 \%$ & 6 & $18.2 \%$ & 9 & $27.3 \%$ & 15 & $45.5 \%$ & 3387 \\
\hline Foshan & 32 & 5 & $15.6 \%$ & 7 & $21.9 \%$ & 12 & $37.5 \%$ & 9 & $28.1 \%$ & 11 & $34.4 \%$ & 20 & $62.5 \%$ & 3430 \\
\hline Fujian & 32 & 4 & $12.5 \%$ & 8 & $25.0 \%$ & 12 & $37.5 \%$ & 8 & $25.0 \%$ & 12 & $37.5 \%$ & 20 & $62.5 \%$ & 3221 \\
\hline Guangdong & 31 & 14 & $45.2 \%$ & 13 & $41.9 \%$ & 27 & $87.1 \%$ & 2 & $6.5 \%$ & 2 & $6.5 \%$ & 4 & $12.9 \%$ & 3358 \\
\hline Guangsha & 32 & 3 & $9.4 \%$ & 14 & $43.8 \%$ & 17 & $53.1 \%$ & 2 & $6.3 \%$ & 13 & $40.6 \%$ & 15 & $46.9 \%$ & 3274 \\
\hline Jilin & 32 & 3 & $9.4 \%$ & 7 & $21.9 \%$ & 10 & $31.3 \%$ & 9 & $28.1 \%$ & 13 & $40.6 \%$ & 22 & $68.8 \%$ & 3242 \\
\hline Jiangsu & 32 & 2 & $6.3 \%$ & 11 & $34.4 \%$ & 13 & $40.6 \%$ & 5 & $15.6 \%$ & 14 & $43.8 \%$ & 19 & $59.4 \%$ & 3282 \\
\hline Liaoning & 32 & 8 & $25.0 \%$ & 11 & $34.4 \%$ & 19 & $59.4 \%$ & 5 & $15.6 \%$ & 8 & $25.0 \%$ & 13 & $40.6 \%$ & 3475 \\
\hline Qingdao & 32 & 2 & $6.3 \%$ & 6 & $18.8 \%$ & 8 & $25.0 \%$ & 10 & $31.3 \%$ & 14 & $43.8 \%$ & 24 & $75.0 \%$ & 3310 \\
\hline Shandong & 32 & 9 & $28.1 \%$ & 14 & $43.8 \%$ & 23 & $71.9 \%$ & 2 & $6.3 \%$ & 7 & $21.9 \%$ & 9 & $28.1 \%$ & 3312 \\
\hline Shanxi & 32 & 4 & $12.5 \%$ & 13 & $40.6 \%$ & 17 & $53.1 \%$ & 3 & $9.4 \%$ & 12 & $37.5 \%$ & 15 & $46.9 \%$ & 3542 \\
\hline Shanghai & 32 & 3 & $9.4 \%$ & 7 & $21.9 \%$ & 10 & $31.3 \%$ & 9 & $28.1 \%$ & 13 & $40.6 \%$ & 22 & $68.8 \%$ & 2952 \\
\hline Tianjin & 32 & 4 & $12.5 \%$ & 7 & $21.9 \%$ & 11 & $34.4 \%$ & 9 & $28.1 \%$ & 12 & $37.5 \%$ & 21 & $65.6 \%$ & 3909 \\
\hline Xinjiang & 32 & 8 & $25.0 \%$ & 14 & $43.8 \%$ & 22 & $68.8 \%$ & 2 & $6.3 \%$ & 8 & $25.0 \%$ & 10 & $31.3 \%$ & 4196 \\
\hline Zhejiang & 32 & 4 & $12.5 \%$ & 12 & $37.5 \%$ & 16 & $50.0 \%$ & 4 & $12.5 \%$ & 12 & $37.5 \%$ & 16 & $50.0 \%$ & 3538 \\
\hline Total & 272 & 94 & $34.6 \%$ & 178 & $65.4 \%$ & & & 94 & $34.6 \%$ & 178 & $65.4 \%$ & & \\
\hline Average & & 5.5294 & & 10.471 & & 16 & & 5.529 & & 10.47 & & 16 & 57775 \\
\hline Standard \\
Deviation
\end{tabular}

Through the analysis of the average and standard deviation, it is found that the total number of victories and the total number of failures are the same. The overall level of the league is equal, and the standard deviation of the number of victories and the number of failures at home and away from home is also substantially the same. The fluctuations of the number of victories and failures of home teams is greater than the visiting teams.

\section{Conclusion}

1. In addition to the results of competition supervision and error rate was positively correlated, the other scorers' score and the error rate was no significant positive correlation.

2. The highest correct rate is the finals, followed by the one-of two finals, the worst is the regular seasons and quarter finals. Missed and error rate is mainly concentrated in the regular season, and the difference between the missed rate is significant. Missed rate and the error rate is very high in the regular season. It shows that CBA referees should also work hard in the basic skills.

3. Referees (R), first deputy referee(U1), second deputy referee(U2), the order of total whistles and correct rate is : R is first, followed by $\mathrm{U} 1$, and finally $\mathrm{U} 2$. Referees should strive to improve the penalty accuracy.

4. There are significant differences in the foul between home teams and visiting teams. There are significant differences in the number of violations between home teams and visiting teams, and there are significant differences between the number of victories of home teams and the number of victories of visiting teams. the number of victories of home teams is more than that of visiting teams. There was a significant difference between the number of failures of home teams and the number of failures of visiting teams, and the number of failures of home teams was less than that of visiting teams.

5. The total number of victories and failures are the same. The overall level of the league is equal. And the standard deviation of home teams' victories and failures are almost the same. The fluctuations of the number of victories and failures of home teams is greater than the visiting teams. 


\section{References}

[1] Meng Guangding. Using Fuzzy Comprehensive Evaluation Method to Evaluate the Work of Referees [J]. Journal of Yanshan University. 1996: 279-282

[2] Hong Canhua, Li Chang. Analysis and Evaluate the Referees' level of the Referees in the Representation Sports Competition Project by Two-Factor Variance [J]. Journal of Physical Education, 1993,10 (4): 82-85.

[3] Jiang Jindong. 2002 National Youth Women's Basketball League referees' error and missed problem [J]. Journal of Xi'an Physical Education Institute, 2003, 20 (5): 61-62.

[4] Yu Zhenfeng, Zhang Jianjun, Yang Shouting, etc. Research on Evaluation Criteria and Computer Evaluation System of China's Young Men Basketball Players' Physical and Basic Technical. [J]. China Sports Science and Technology. 2000,36 (11): 17-22.

[5] Yu Zhenfeng, Zhang Jianjun, Yang Shouting, etc. Research on the evaluation criteria and computer evaluation system of the young men's basketball players' physical fitness and basic technology [J]. China Sports Science and Technology. 2000,36 (11): 17-22.

[6] Wei Xianjun. Research on Computer Evaluation System and Establishment of Physical Fitness Evaluation Model of Juvenile Male Soccer Players in Jiangsu Province [D]. Master's Thesis, Nanjing Normal University, 2003: 16-29.

[7] Deng Hong. Basketball Association Recognized that Four Judges and a Technical Representative of CBA Has Been Suspended [N]. Beijing Entertainment News, 2009-1-16. 